\title{
THE IMPLEMENTATION OF COOPERATIVE MODEL STUDENT TEAMS ACHIEVEMENT DIVISIONS TYPE TO INCREASE THE ACTIVITIES AND RESULT OF STUDENTS LEARNING IN LEARN THE BASIC TECHNIQUE FOOT BALL PASSING CONTROL
}

\author{
Made Gunawan Adi W, I Wayan Artanayasa, Kadek Yogi Parta Lesmana \\ Penjaskesrek FOK Universitas Pendidikan Ganesha \\ Singaraja Indonesia \\ Email: made gunawan@gmail.com, wayan.artanayasa@undiksha.ac.id , \\ yogi.partalesmana@undiksha.ac.id
}

\begin{abstract}
Abstrak
Penelitian ini bertujuan untuk meningkatkan aktivitas dan hasil belajar teknik dasar passing control sepakbola bola melalui melalui model pembelajaran kooperatif tipe STAD pada siswa kelas X 6 A SMA Karya Wisata Singaraja Tahun Pelajaran 2016/2017. Penelitian ini tergolong penelitian tindakan kelas dengan bentuk guru sebagai peneliti, yang dilaksanakan dalam dua siklus dan setiap siklus terdiri dari dua kali pertemuan. Subjek penelitian ini adalah 34 orang, terdiri dari 20 orang putra dan 14 orang putri, yang dianalisis menggunakan analisis statistik deskriptif. Berdasarkan analisis data aktivitas belajar pada observasi awal siswa aktif 5 orang $(11,8 \%)$, setelah diberikan tindakan pada siklus I, siswa aktif meningkat menjadi 10 orang $(32,35 \%)$, setelah pemberian tindakan pada siklus II, siswa aktif meningkat menjadi 34 orang $(100 \%)$. Sedangkan berdasarkan analisis data hasil belajar siklus I pada aspek sikap siswa tuntas 8 orang (23,53\%), pada aspek pengetahuan siswa tuntas 19 orang $(55,88 \%)$, dan pada aspek keterampilan siswa tuntas 10 orang $(29,41 \%)$. Sedangkan siklus II pada aspek sikap siswa tuntas 34 orang $(100 \%)$, aspek pengetahuan siswa tuntas 34 orang (100\%), dan aspek keterampilan siswa tuntas 34 orang $(100 \%)$. Kesimpulan penelitian ini adalah aktivitas dan hasil belajar teknik dasar passing control sepakbola bola melalui melalui model pembelajaran kooperatif tipe STAD pada siswa kelas X 6 A SMA Karya Wisata Singaraja Tahun Pelajaran 2016/2017. Disarankan kepada guru Penjasorkes dapat menerapkan model pembelajaran kooperatif tipe STAD karena dapat meningkatkan aktivitas dan hasil belajar teknik dasar passing control sepakbola
\end{abstract}

Kata-kata Kunci: Kooperatif, aktivitas, hasil belajar, sepakbola.

\section{ABSTRACT}

This research aimed to increase the activities and result of learning the basic technique of football passing control though the implementation of cooperative teaching model STAD type to the students in grade ten six SMA Karya Wisata in 2016/2017. This research was categories action research where the teacher was as the researcher. This research was done in 2 cycles and every cycle consist of 2 meeting. The subject was 34 students who consisted of 20 males and 14 females. The subject was analysed by using descriptive statistical analysis. Based on the analysis, the students' learning activities in preliminary observation was $5(11,8 \%)$ students were active, then after giving the measure in cycle 1 , the students who were active increased become 10 students $(32,35)$ and in the cycle 2 , the students were active increased become 34 students (100\%). Meanwhile based on the data analysis of the result of students learning process, in cycle 1 in affective aspect there were 8 students $(23,53)$, who pass their learning, then in cognitive aspect there were 19 students $(55.88 \%)$ who pass their learning, and in psychomotor aspect there were 10 student $(29.41 \%)$ students who pass their learning. While in the cycle 2 all of the learning aspects gave a significant increase become $100 \%$. Based on the result of the data analysis, it could be concluded that this research was success. The activity and the result of students learning the basic technique in football passing control through implementation the cooperative model STAD type to the students in grade ten six SMA Karya Wisata in 2016/2017. It was suggested to the teacher to implement this teaching model STAD because because it can increase the activity and results of learning the basic techniques football of passing control 
Key word : cooperative, activities, result of learning, football

\section{PENDAHULUAN}

Pendidikan jasmani olahraga dan kesehatan merupakan proses pendidikan yang memanfaatkan aktivitas jasmani (fisik) dan kesehatan yang dijadikan sebagai media untuk menghasilkan perubahan dalam perkembangan individu secara menyeluruh. Pendidikan jasmani olahraga dan kesehatan (Penjasorkes) merupakan bagian integral dari pendidikan secara keseluruhan, bertujuan untuk mengembangkan aspek kebugaran jasmani, keterampilan gerak, keterampilan berpikir kritis, keterampilan sosial, penalaran, stabilitas emosional, tindakan moral, aspek pola hidup sehat dan pengenalan lingkungan bersih melalui aktivitas jasmani, olahraga dan kesehatan terpilih yang direncanakan secara sistematis dalam rangka mencapai tujuan pendidikan nasional.

Begitu pentingnya peran dan tujuan pendidikan khususnya penjasorkes, maka mutu pendidikan haruslah ditingkatkan. Salah satu upaya untuk meningkatkan mutu pendidikan adalah melalui peningkatan kualitas pembelajaran, diantaranya dengan cara memilih metode pembelajaran yang tepat. Guru diharapkan mampu menciptakan situasi pembelajaran yang dapat menarik minat siswa dalam melaksanakan proses pembelajaran penjasorkes. Dalam pembelajaran ini, guru dituntut mengajarkan berbagai keterampilan gerak dasar, teknik dan strategi permainan/olahraga, internalisasi nilai-nilai sportivitas, jujur, kerjasama, empati, sehingga siswa dapat memperoleh berbagai pengalaman untuk mengungkapkan kesan pribadi yang menyenangkan, kreatif, inovatif, terampil, meningkatkan dan memelihara kebugaran jasmani serta pemahaman terhadap gerak manusia. Penjasorkes sebagai mata pelajaran yang menitik beratkan pada ranah psikomotor tetapi juga tidak mengabaikan ranah kognitif maupun ranah afektif.

Berdasarkan data observasi awal peneliti dan hasil wawancara dengan guru penjasorkes dan siswa khususnya di kelas Siswa Kelas X 6 A SMA Karya Wisata Singaraja pada pembelajaran Penjasorkes khususnya pada materi teknik dasar passing control sepakbola, masih banyak siswa yang kurang mampu melakukan teknik dasar passing control yang benar. Hal tersebut disebabkan karena guru masih belum menyesuaikan dalam pemilihan model pembelajaran, guru masih mempergunakan model pembelajaran tradisional. Dalam model pembelajaran tradisional pembelajaran masih terpusat pada guru dan pembelajaran menekankan pada metode ceramah sehingga siswa lebih banyak diam atau kurang aktif dan bersifat individual dalam mengikuti pelajaran.. Adapun hasil observasi awal yang peneliti lakukan di kelas Siswa Kelas X 6 A SMA Karya Wisata Singaraja dengan jumlah siswa 30 orang dan berpedoman pada konversi nilai mata pelajaran penjasorkes Siswa Kelas $X$ 6 A SMA Karya Wisata Singaraja, dengan nilai Kriteria Ketuntasan Minimal (KKM) yaitu $70 \%$ dan nilai klasikal sebesar $75 \%$, maka ada $60 \%$ yang belum memenuhi nilai KKM dan nilai ketuntasan belajar secara klasikal yaitu $40 \%$.

Begitu juga halnya dengan hasil belajar siswa, terdapat masalahmasalah yang ditemukan dalam melakukan gerakan passing control yang mengakibatkan hasil belajar siswa belum mencapai tingkat ketuntasan yaitu dari sikap awalan, sikap pelaksanaan dan sikap akhir. Masalah yang dihadapi saat melakukan sikap awalan passing baik 
dengan kaki bagian dalam maupun kaki bagian luar adalah pada saat meletakkan kaki tumpu masih ada yang tidak tepat di samping bola dan kaki tumpu masih kurang ditekuk. Pada sikap pelaksanaan passing baik dengan kaki bagian dalam maupun kaki bagian luar adalah pada saat melakukan gerakan pasing pergelangan kaki kurang ditegangkan sehingga arah bola tidak mau menggelinding ke depan dan gerakan badan masih kurang condong ke depan. Sedangkan masalah yang ditemukan pada sikap akhir passing baik dengan kaki bagian dalam maupun kaki bagian luar adalah gerakan lanjutan kaki setelah menendang bola belum ada dan pandangan masih kurang fokus pada bola. Sedangkan masalah yang dihadapi pada saat melakukan sikap awalan control baik dengan kaki bagian dalam maupun bagian luar adalah kaki tumpu tidak mengarah pada saat datangnya bola, lutut masih kurang sedikit ditekuk dan kaki penahan kurang diangkat sedikit dengan menjulurkan kaki yang digunakan menahan bola kedepan segaris dengan datanya bola. Pada sikap pelaksanaan control baik dengan kaki bagian dalam maupun kaki bagian luar adalah kaki penerima bola belum digerakan ke depan menjemput datangnya bola, bola menyentuh kaki tidak tepat pada bagian dalam atau bagian luar kaki dan kaki penahan tidak megikuti arah datanya bola. Sedangkan masalah yang ditemukan pada sikap akhir control baik dengan kaki bagian dalam maupun kaki bagian luar adalah pada saat meletakkan kaki penerima bola dalam posisi kurang tegak lurus dengan ujung tumit kaki tumpu dan penguasaan bola juga masih agak jauh dari kaki.

Bertolak dari pemaparan di atas, peneliti akan mencoba memberikan alternatif pemecahan masalah untuk mengatasi masalah yang muncul, yaitu dengan menerapkan model pembelajaran kooperatif tipe Student Teams Achievement Divisions (STAD). Tipe ini dipandang sebagai yang paling sederhana dan paling langsung dari model pembelajaran kooperatif. Penerapkan model pembelajaran kooperatif tipe STAD merupakan penataan lingkungan atau suasana belajar yang berfokus pada siswa, dimana dalam pembelajaran siswa akan belajar dalam kelompok. Di dalam kelompok siswa diharapkan bisa saling membantu dan siswa terlibat secara aktif untuk memecahkan masalah atau menguasai materi yang diberikan oleh guru. Penerapan model pembelajaran kooperatif tipe STAD memiliki suatu keunggulan yaitu, suasana belajar selama kegiatan PBM nampak bebas, ceria, gairah, dan kondusif dan siswa dapat berkolaborasi dengan teman sehingga lebih mudah memecahkan masalah yang dihadapi dalam proses pembelajaran. Dengan demikian siswa pada proses pembelajaran dilapangan akan dirangsang untuk menemukan, saling membantu, dan saling memperbaiki kesalahan pada pembelajaran teknik dasar passing control sepakbola seperti cara melakukan sikap awalan, sikap pelaksanaan dan sikap akhir.Berdasarkan uraian keseluruhan di atas, peneliti ingin melakukan penelitian dengan judul "Penerapan Model Pembelajaran Kooperatif Tipe Student Teams Achievement Divisions (STAD) Untuk Meningkatkan Aktivitas dan Hasil Belajar Teknik Dasar Passing Conrol Sepakbola Pada Siswa Kelas X 6 A SMA Karya Wisata Singaraja Tahun Pelajaran 2016/2017.

Adapun tujuan yang hendak dicapai dalam penelitian ini adalah sebagai berikut :

1. Untuk meningkatkan aktivitas belajar teknik dasar passing control sepakbola melalui model 
pembelajaran kooperatif tipe STAD pada siswa kelas $\times 6$ A SMA Karya Wisata Singaraja Tahun Pelajaran 2016/2017.

2. Untuk meningkatkan hasil belajar teknik dasar passing control sepakbola melalui model pembelajaran kooperatif tipe STAD pada siswa kelas $X 6 \mathrm{~A}$ SMA Karya Wisata Singaraja Tahun Pelajaran 2016/2017.

\section{METODE PENELITIAN}

Jenis penelitian adalah penelitian tindakan kelas (PTK). Kanca I Nyoman, (2010: 108). Menyatakan bahwa "PTK didefinisikan sebagai sesuatu bentuk penelitian yang bersifat reflektif dengan melakukan tindakan-tindakan tertentu agar dapat memperbaiki dan atau meningkatkan praktik- praktik pembelajaran di kelas secara prefisional. Penelitian ini dilaksanakan di kelas X 6 A SMA Karya Wisata Singaraja pelajaran 2016/2017. Dilaksanakan sebanyak 2 siklus, dengan masing-masing siklus terdiri dari 2 kali pertemuan.

Masing-masing siklus terdiri dari empat tahapan yaitu: (1) perencanaan, (2) pelaksanaan tindakan, (3) observasi/evaluasi dan (4) refleksi. Adapun prosedur penelitian dalam penelitian ini yaitu:

(a) Observasi awal, (b) Refleksi awal,

(c) Identifikasi masalah, (d) Analisis masalah, (e) Perumusan masalah, (f) Merumuskan hipotesis tindakan, (g) Pelaksanaan penelitian.

Teknik pengumpulan data yang digunakan dalam penelitian ini terdiri dari pengumpulan data aktivitas dan hasil belajar. Data aktivitas belajar dikumpulkan pada setiap pertemuan pada setiap siklus yang dilakukan oleh 2 orang evaluator yaitu 2 orang guru Penjasorkes SMA Karya Wisata Singaraja. Sedangkan data hasil belajar dikumpulkan pada pertemuan kedua setiap siklus dimana aspek sikap dilakukan oleh peneliti sendiri, aspek pengetahuan dilakukan oleh peneliti sendiri, dan keterampilan dilakukan oleh 2 orang evaluator yaitu 2 orang guru Penjasorkes SMA Karya Wisata Singaraja

Dalam penelitian ini, teknik analisis data yang digunakan adalah analisis statistik deskriptif. Statistik deskriptif dapat digunakan untuk mengolah karakteristik data yang berkaitan dengan menjumlah, meratarata, mencari titik tengah, mencari persentase, dan menyajikan data yang menarik, mudah dibaca dan diikuti alur berpikirnya.

\section{HASIL DAN PEMBAHASAN}

Penelitian ini dilaksanakan dari tanggal 6 Januari 2017 sampai 6 Februari 2017 yang dilaksanakan setiap pukul 06.00-08.00 WITA, bertempat di Lapangan Penarukan Singaraja, dengan subjek penelitiannya adalah X 6 A SMA Karya Wisata Singaraja pelajaran 2016/2017 yang berjumlah 34 orang dengan perincian 20 orang siswa putra dan 14 orang siswa putri. Penelitian ini dilaksanakan sebanyak dua siklus, disetiap siklus terdapat dua kali pertemuan. Siklus I pertemuan pertama dilaksanakan pada tanggal 6 Januari 2017, pertemuan kedua dilaksanakan pada tanggal 13 Januari 2017. Sedangkan siklus II pertemuan pertama dilaksanakan pada tanggal 20 Januari 2017, pertemuan kedua dilaksanakan pada tanggal 6 Februari 2017.

hasil analisis data aktivitas belajar teknik passing control sepakbola pada siswa kelas X 6 A SMA Karya Wisata Singaraja Tahun Pelajaran 2016/2017 dapat diketahui bahwa, pada observasi awal siswa yang sudah aktif 4 orang (11,8\%), setelah diberikan tindakan pada siklus I, siswa yang sudah aktif menjadi 11 orang $(32,35 \%)$ dengan peningkatan 7 orang (20,58\%). Kemudian 
dilanjutkan dengan pemberian tindakan pada siklus II, siswa yang aktif pada siklus II yaitu 34 orang $(100 \%)$ dengan peningkatan 23 orang
$(67,64 \%)$ dari siklus I. Pada siklus II semua siswa sudah tergolong aktif 34 orang $(100 \%)$.

Tabel 0.1 Hasil Analisis Data Aktivitas Belajar Teknik Dasar Passing control sepakbola Pada Siklus I.

\begin{tabular}{|c|c|c|c|c|c|}
\hline No & Kriteria & $\begin{array}{c}\text { Jumlah } \\
\text { siswa } \\
\text { (orang) }\end{array}$ & $\begin{array}{c}\text { Persentase } \\
(\%)\end{array}$ & Kategori & $\begin{array}{c}\text { Keaktifan } \\
\text { siswa }\end{array}$ \\
\hline 1 & $\bar{X} \geq 9$ & 0 & 0 & \multirow{6}{*}{$\begin{array}{c}\text { Sangat Aktif } \\
\text { Aktif } \\
\text { Cukup Aktif } \\
\text { Kurang Aktif } \\
\text { Sangat Kurang } \\
\text { Aktif }\end{array}$} & 11 orang \\
\hline 2 & $7 \leq \bar{X}<9$ & 11 & 32,35 & & Sudah aktif \\
\hline 3 & $5 \leq \bar{X}<7$ & 22 & 67,6 & & \\
\hline 4 & $3 \leq \bar{X}<5$ & 1 & 2,94 & & $\begin{array}{c}23 \text { orang } \\
(67,6 \%)\end{array}$ \\
\hline 5 & $\bar{X}<3$ & 0 & 0 & & Belum Akti \\
\hline & Jumlah & 34 & 100 & & $\begin{array}{c}34 \text { orang } \\
(100 \%)\end{array}$ \\
\hline
\end{tabular}

Hasil analisis data hasil belajar aspek sikap teknik dasar passing control sepakbola pada siklus I, diperoleh data hasil belajar dimana siswa yang tuntas 8 orang $(23,53 \%)$ dan yang tidak tuntas 26 orang $(76,47 \%)$. Adapun rincian kategori hasil belajar pada aspek sikap siswa sebagai berikut: siswa dalam katagori sangat baik tidak ada (0\%), kategori baik 8 orang (23,53\%), kategori cukup 18 orang $(52,9 \%)$, dan kategori kurang 8 orang $(23,53 \%)$, dengan persentase secara klasikalnya 62,16. Hasil analisis data hasil belajar aspek sikap teknik dasar passing control sepakbola pada siswa X 6 A SMA Karya Wisata Singaraja Tahun Pelajaran 2016/2017 disajikan pada tabel 0.2.

Tabel 0.2 Hasil Analisis Data Hasil Belajar Aspek Sikap Teknik Dasar Passingcontrol sepakbola Basket pada Siklus I

\begin{tabular}{|c|c|c|c|c|c|}
\hline No & Modus & Predikat & $\begin{array}{c}\text { Jumlah } \\
\text { Siswa } \\
\text { (orang) }\end{array}$ & $\begin{array}{c}\text { Persentase } \\
(\%)\end{array}$ & Keterangan \\
\hline 1 & $86-100$ & Sangat Baik & 0 & 0 & 8 orang $(23,53 \%)$ \\
\hline 2 & $71-85$ & Baik & 8 & 23,53 & \\
\hline 3 & $56-70$ & Cukup Baik & 18 & 52,90 & 26 orang $(76,47 \%)$ \\
\hline 4 & $\leq 55$ & Kurang Baik & 8 & 23,53 & Tidak Tuntas \\
\hline \multicolumn{3}{|c|}{ Jumlah } & 34 & $100 \%$ & 34 orang $(100 \%)$ \\
\hline \multicolumn{4}{|c|}{$\begin{array}{l}\text { Hasil analisis data hasil belajar } \\
\text { pengetahuan teknik dasar } \\
\text { g passing control sepakbola } \\
\text { siklus I, diperoleh data hasil } \\
\text { r dimana siswa yang tuntas } 19 \\
(55,88 \%) \text { dan yang tidak tuntas } \\
\text { ang }(44,1 \%) \text {. Adapun rincian }\end{array}$} & \multicolumn{2}{|c|}{$\begin{array}{l}\text { kategori hasil belajar pada aspek } \\
\text { pengetahuan } \\
\text { siswa sebagai berikut: siswa dengan } \\
\text { katagori sangat baik tidak ada }(0 \%) \text {, } \\
\text { kategori baik } 19 \text { orang }(55,88 \%) \text {, } \\
\text { kategori cukup } 4 \text { orang }(11,76 \%) \text {, dan } \\
\text { kategori kurang } 11 \text { orang }(32,4 \%) \text {, } \\
\text { dengan persentase secara klasikalnya } \\
65,64 \text {. Hasil analisis data hasil belajar }\end{array}$} \\
\hline
\end{tabular}


aspek pengetahuan teknik dasar passing passingcontrol sepakbola pada siswa X 6 A SMA Karya Wisata Singaraja Tahun Pelajaran 2016/2017 disajikan pada tabel 0.3 .

Tabel 0.3 Hasil Analisis Data Hasil Belajar Aspek Pengetahuan Teknik Dasar passing control sepakbola pada Siklus I

\begin{tabular}{cccccc}
\hline No & $\begin{array}{c}\text { Rentang Nilai } \\
\text { Skala 1-100 }\end{array}$ & Predikat & $\begin{array}{c}\text { Jumlah } \\
\text { Siswa } \\
\text { (orang) }\end{array}$ & Kategori & Keterangan \\
\hline 1 & $86-100$ & A & 0 & Sangat Baik & 19 orang $(55,88 \%)$ \\
2 & $71-85$ & B & 19 & Baik & Tuntas \\
3 & $56-70$ & C & 4 & Cukup & 15 orang $(44,1 \%)$ \\
4 & $\leq 55$ & D & 11 & Kurang & Tidak Tuntas \\
& & & 34 & & 34 Orang (100\%) \\
\hline
\end{tabular}

Hasil analisis data hasil belajar aspek keterampilan teknik dasar passing control sepakbola pada siklus I, diperoleh data hasil belajar dimana siswa yang tuntas 10 orang $(27,03 \%)$ dan yang tidak tuntas 27 orang (72,97\%). Adapun rincian kategori hasil belajar pada aspek keterampilan siswa sebagai berikut: siswa dalam katagori sangat baik tidak ada $(0 \%)$, kategori baik 10 orang $(27,03 \%)$, kategori cukup 17 orang (50\%), dan kategori kurang 7 orang (20,59\%), dengan persentase secara klasikalnya 66,12 . Hasil analisis data hasil belajar aspek keterampilan teknik dasar passing control sepakbola pada siswa kelas $X \quad 6$ A SMA Karya Wisata Singaraja Tahun Pelajaran 2016/2017 disajikan pada tabel 0.4.

Tabel 0.4 Hasil Analisis Data Hasil Belajar Aspek Keterampilan Teknik Dasar Passing Control Sepak Bola pada Siklus I

\begin{tabular}{|c|c|c|c|c|c|}
\hline No & $\begin{array}{c}\text { Rentang Nilai } \\
\text { Skala 1-100 }\end{array}$ & Predikat & $\begin{array}{c}\text { Jumlah } \\
\text { Siswa } \\
\text { (orang) }\end{array}$ & Kategori & Keterangan \\
\hline 1 & $86-100$ & $A$ & 0 & \multirow{2}{*}{$\begin{array}{c}\text { Sangat Baik } \\
\text { Baik }\end{array}$} & \multirow{4}{*}{$\begin{array}{c}10 \text { orang } \\
(27,03 \%) \text { Tuntas } \\
27 \text { orang } \\
(72,97 \%) \text { Tidak } \\
\text { Tuntas }\end{array}$} \\
\hline 2 & $71-85$ & B & 10 & & \\
\hline 3 & $56-70$ & C & 17 & Cukup & \\
\hline 4 & $\leq 55$ & $\mathrm{D}$ & 7 & Kurang & \\
\hline & Jumlah & & 34 & & 34 orang $(100 \%)$ \\
\hline
\end{tabular}

Pada siklus II dilakukan tindakan sesuai hasil refleksi dari tindakan siklus I. Dari tindakan tersebut terjadi peningkatan pada aktivitas dan hasil belajar siswa. Hal ini terbukti sesuai data aktivitas dan hasil belajar pada siklus II. Hasil analisis data aktivitas belajar pada siklus II diperoleh aktivitas belajar siswa secara klasikal sebesar 7,87.

Siswa yang sudah aktif 34 orang (100\%) dan tidak ada siswa yang tidak aktif (0\%). Adapun rinciannya yaitu siswa dengan kategori sangat aktif 3 orang $(8,82 \%)$, siswa dengan kategori aktif 31 orang $(91,18 \%)$, siswa dengan kategori 
cukup aktif tidak ada (0\%), siswa dengan kategori kurang aktif tidak ada $(0 \%)$, dan siswa dengan kategori sangat kurang aktif tidak ada (0\%). Hasil analisis data aktivitas belajar teknik passing control sepakbola pada siklus II disajikan pada tabel 0.5 .

Tabel 0.5 Hasil Analisis Data Aktivitas Belajar Teknik Dasar Passing Control Sepak Bola pada Siklus II

\begin{tabular}{|c|c|c|c|c|c|}
\hline No & Kriteria & $\begin{array}{c}\text { Jumlah } \\
\text { siswa } \\
\text { (orang) }\end{array}$ & $\begin{array}{c}\text { Persentase } \\
\text { (\%) }\end{array}$ & Kategori & $\begin{array}{l}\text { Keaktifan } \\
\text { siswa }\end{array}$ \\
\hline 1 & $\bar{X} \geq 9$ & 3 & 8,82 & Sangat Aktif & \\
\hline 2 & $7 \leq \bar{X}<9$ & 31 & 91,18 & Aktif & $\begin{array}{c}(100 \%) \\
\text { Sudah aktif }\end{array}$ \\
\hline 3 & $5 \leq \bar{X}<7$ & 0 & 0 & Cukup Aktif & \\
\hline 4 & $3 \leq \bar{X}<5$ & 0 & 0 & Kurang Aktif & $\begin{array}{l}\text { I Idak ada } \\
(0 \%)\end{array}$ \\
\hline 5 & $\bar{X}<3$ & 0 & 0 & $\begin{array}{c}\text { Sangat Kurang } \\
\text { Aktif }\end{array}$ & Tidak Aktif \\
\hline & Jumlah & 34 & & & $\begin{array}{c}34 \text { orang } \\
(100 \%)\end{array}$ \\
\hline \multicolumn{4}{|c|}{$\begin{array}{l}\text { Hasil analisis data hasil belajar } \\
\text { sikap teknik dasar passing } \\
\text { sepakbola pada siklus II, } \\
\text { leh data hasil belajar dimana } \\
\text { yang tuntas sebanyak } 34 \text { orang } \\
\text { ) dan yang tidak tuntas tidak } \\
0 \% \text { ). Adapun rincian kategori } \\
\text { pelajar pada aspek sikap siswa } \\
\text { katagori sangat baik } 10 \text { orang }\end{array}$} & \multicolumn{2}{|c|}{$\begin{array}{l}(29,41 \%) \text {, kategori baik } 24 \text { orang } \\
(70,59 \%) \text {, kategori cukup tidak ada } \\
(0 \%) \text {, dan kategori kurang tidak ada } \\
(0 \%) \text {, dengan persentase secara } \\
\text { klasikalnya } 82,5 \% \text {. Hasil analisis data } \\
\text { hasil belajar aspek sikap teknik dasar } \\
\text { passing control sepakbola pada siswa } \\
\text { kelas X } 6 \text { AMA Karya Wisata } \\
\text { Singaraja Tahun Pelajaran } 2016 / 2017 \\
\text { disajikan pada tabel } 0.6 \text {. }\end{array}$} \\
\hline
\end{tabular}

Tabel 0.6 Hasil Analisis Data Hasil Belajar Aspek Sikap Teknik Dasar passing control Sepakbola pada Siklus II

\begin{tabular}{|c|c|c|c|c|c|}
\hline No & Modus & Predikat & $\begin{array}{c}\text { Jumlah } \\
\text { Siswa } \\
\text { (orang) }\end{array}$ & $\begin{array}{c}\text { Persentase } \\
(\%)\end{array}$ & Keterangan \\
\hline 1 & $86-100$ & Sangat Baik & 10 & 29,41 & 34 orang (100\%) \\
\hline 2 & $71-85$ & Baik & 24 & 70,59 & Tuntas \\
\hline 3 & $56-70$ & Cukup Baik & 0 & 0 & 0 orang $(0 \%)$ \\
\hline 4 & $\leq 55$ & Kurang Baik & 0 & 0 & Tidak Tuntas \\
\hline \multicolumn{3}{|c|}{ Jumlah } & 34 & $100 \%$ & 34 orang $(100 \%)$ \\
\hline \multicolumn{4}{|c|}{$\begin{array}{l}\text { Hasil analisis data hasil belajar } \\
\text { pengetahuan teknik dasar } \\
\text { g control sepakbola pada siklus } \\
\text { eroleh data hasil belajar dimana } \\
\text { yang tuntas } 34 \text { orang (100\%) } \\
\text { dak ada siswa yang tidak tuntas }\end{array}$} & \multicolumn{2}{|c|}{$\begin{array}{l}\text { (0\%). Adapun rincian kategori hasi } \\
\text { belajar pada aspek pengetahuan } \\
\text { siswa sebagai berikut: siswa dengan } \\
\text { katagori sangat baik } 12 \text { orang } \\
(35,29 \%) \text {, kategori baik } 22 \text { orang } \\
(64,71 \%) \text {, kategori cukup tidak ada } \\
(0 \%) \text {, dan kategori kurang tidak ada }\end{array}$} \\
\hline
\end{tabular}


(0\%), dengan persentase secara klasikalnya 84,7. Hasil analisis data hasil belajar aspek pengetahuan teknik dasar passing control sepakbola pada siswa kelas X 6 A SMA Karya Wisata Singaraja Tahun Pelajaran 2016/2017 disajikan pada tablel

Tabel 0.7 Hasil Analisis Data Hasil Belajar Aspek Pengetahuan Teknik passing control Sepakbola pada Siklus II

\begin{tabular}{|c|c|c|c|c|c|}
\hline No & $\begin{array}{c}\text { Rentang Nilai } \\
\text { Skala 1-100 }\end{array}$ & Predikat & $\begin{array}{l}\text { Jumlah } \\
\text { Siswa } \\
\text { (orang) }\end{array}$ & Kategori & Keterangan \\
\hline 1 & $86-100$ & A & 12 & & \\
\hline 2 & $71-85$ & B & 22 & $\begin{array}{l}\text { Sangat Balk } \\
\text { Baik }\end{array}$ & $\begin{array}{c}34 \text { orang }(100 \%) \\
\text { Tuntas }\end{array}$ \\
\hline $\begin{array}{l}3 \\
4\end{array}$ & $\begin{array}{l}56-70 \\
\leq 55\end{array}$ & $\begin{array}{l}C \\
D\end{array}$ & $\begin{array}{l}0 \\
0\end{array}$ & $\begin{array}{l}\text { Cukup } \\
\text { Kurang }\end{array}$ & $\begin{array}{l}0 \text { orang }(0 \%) \\
\text { Tidak Tuntas }\end{array}$ \\
\hline
\end{tabular}

Jumlah 34

Hasil analisis data hasil belajar aspek keterampilan teknik dasar passing control sepakbola pada siklus II, diperoleh data hasil belajar dimana siswa yang tuntas 34 orang (100\%) dan tidak tuntas tidak ada (0\%). Adapun rincian kategori hasil belajar pada aspek keterampilan siswa sebagai berikut: siswa dalam katagori sangat baik 17 orang (50\%), kategori
34

baik 17 orang (50\%), kategori cukup tidak ada $(0 \%)$, dan kategori kurang tidak ada (0\%), dengan persentase secara klasikalnya 84,99. Hasil analisis data hasil belajar aspek keterampilan teknik dasar passing control sepakbola pada siswa kelas $X$ 6 A SMA Karya Wisata Singaraja Tahun Pelajaran 2016/2017 disajikan pada tabel 0.8 .

Tabel 0.8 Hasil Analisis Data Hasil Belajar Aspek Keterampilan Teknik Dasar Passing Control Sepak Bola pada Siklus II

\begin{tabular}{|c|c|c|c|c|c|}
\hline No & $\begin{array}{l}\text { Rentang Nilai } \\
\text { Skala 1-100 }\end{array}$ & Predikat & $\begin{array}{c}\text { Jumlah } \\
\text { Siswa } \\
\text { (orang) }\end{array}$ & Kategori & Keterangan \\
\hline 1 & $86-100$ & $A$ & 17 & Sangat & \\
\hline 2 & $71-85$ & B & 17 & $\begin{array}{l}\text { Baik } \\
\text { Baik }\end{array}$ & $\begin{array}{c}34 \text { orang }(100 \%) \\
\text { Tuntas }\end{array}$ \\
\hline $\begin{array}{l}3 \\
4\end{array}$ & $\begin{array}{l}56-70 \\
\leq 55\end{array}$ & $\begin{array}{l}C \\
D\end{array}$ & $\begin{array}{l}0 \\
0\end{array}$ & $\begin{array}{l}\text { Cukup } \\
\text { Kurang }\end{array}$ & $\begin{array}{l}0 \text { orang }(0 \%) \\
\text { Tidak Tuntas }\end{array}$ \\
\hline & Jumlah & & 34 & & 34 \\
\hline
\end{tabular}


Tabel 9. Peningkatan Hasil Belajar Aspek Keterampilan Passing Control Sepak Bola

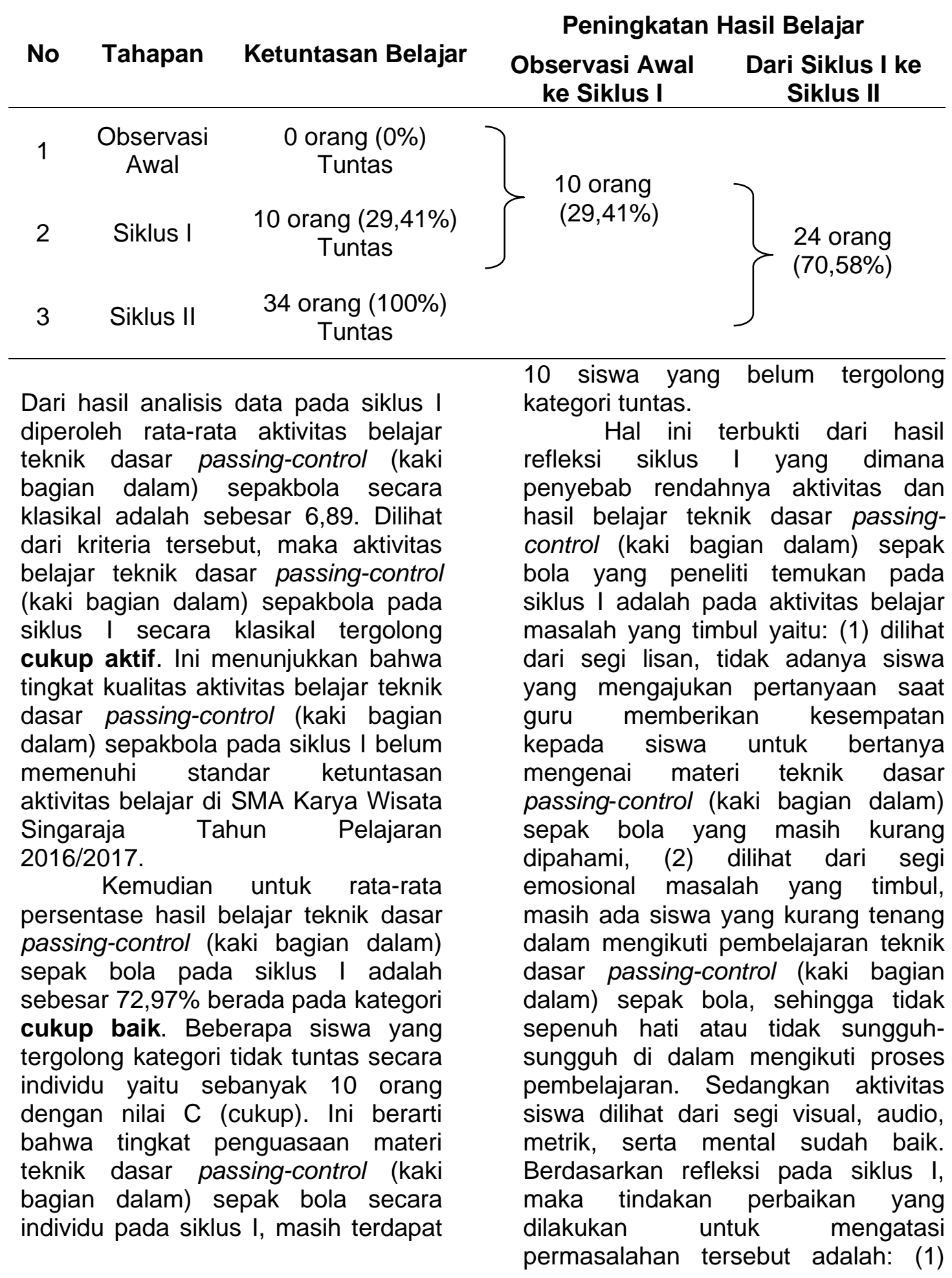


peneliti memotivasi dan apresiasi atas usaha yang dilakukan siswa, dan menyarankan kepada siswa agar berani mengemukakan pendapat kepada temannya sesuai dengan pengetahuan yang mereka miliki sendiri, (2) peneliti menyarankan kepada siswa agar tetap tenang dan percaya diri karena ketakutan dalam pikiranlah yang menyebabkan siswa tidak mampu melakukan gerakan teknik dasar passing-control (kaki bagian dalam) sepak bola dengan benar. Untuk hasil belajar siswa dapat dijelaskan bahwa: (1) untuk aspek kognitifnya sudah berada dalam kategori baik, (2) untuk aspek afektif juga sudah baik, (3) pada aspek psikomotor permasalahan yang terjadi adalah saat melakukan sikap awal passing (kaki bagian dalam) sepak bola yaitu saat melakukan sikap awal passing (kaki bagian dalam) sepak bola adalah pada saat meletakkan kaki tumpu masih ada yang tidak tepat di samping bola. Pada sikap pelaksanaan passing dengan kaki bagian dalam adalah pada saat melakukan gerakan passing pergelangan kaki kurang ditegangkan sehingga arah bola tidak mau menggelinding ke depan dan gerakan badan masih kurang condong ke depan. Sedangkan masalah yang ditemukan pada sikap akhir passing (kaki bagian dalam) sepak bola adalah gerakan akhir kaki setelah menendang bola belum ada dan pandangan masih kurang fokus pada bola. Sedangkan masalah yang dihadapi pada saat melakukan sikap awal control (kaki bagian dalam) sepak bola adalah kaki tumpu tidak mengarah pada saat datangnya bola, lutut masih kurang sedikit ditekuk dan kaki penahan kurang diangkat sedikit dengan menjulurkan kaki yang digunakan menahan bola kedepan segaris dengan datangnya bola. Pada sikap pelaksanaan control (kaki bagian dalam) sepak bola adalah kaki penerima bola belum digerakan ke depan menjemput datangnya bola dan kaki penahan tidak megikuti arah datangnya bola. Sedangkan masalah yang ditemukan pada sikap akhir control (kaki bagian dalam) sepak bola adalah pada saat meletakkan kaki penerima bola dalam posisi kurang tegak lurus dengan ujung tumit kaki tumpu dan penguasaan bola juga masih agak jauh dari kaki. Berdasarkan permasalahan tersebut, maka tindakan perbaikan yang dilakukan adalah: (1) peneliti menjelaskan kembali dan memberikan tindakan langsung kepada siswa tentang materi teknik dasar passing-control (kaki bagian dalam) sepak bola secara bertahap, (2) memberikan bimbingan kepada siswa yang masih salah dalam melakukan gerakan teknik dasar passing-control (kaki bagian dalam) sepak bola mulai dari sikap awal, pelaksanaan, dan sikap akhir sehingga hasil yang diperoleh bisa lebih optimal.

Berdasarkan hasil refleksi pada siklus I, maka pelaksanaan penelitian ini dilanjutkan ke siklus II. Hasil dari refleksi siklus I ini yang nantinya akan digunakan sebagai referensi dalam melaksanakan penelitian pada siklus II dengan tujuan untuk dapat meningkatkan aktivitas dan hasil belajar yang lebih baik. Adapun hasil analisis data pada siklus II, yaitu dimana untuk aktivitas belajar teknik dasar passing-control (kaki bagian dalam) sepak bola secara klasikal diperoleh sebesar 8,89 yang tergolong kategori aktif. Dari hasil data aktivitas belajar tersebut dapat dikatakan bahwa aktivitas belajar teknik dasar passing-control (kaki bagian dalam) sepak bola pada siklus I ke siklus II mengalami peningkatan sebesar 2,00 dari 6,89 menjadi 8,89.

Sedangkan untuk rata-rata persentase hasil belajar teknik dasar passing-control (kaki bagian dalam) sepak bola pada siklus II diperoleh sebesar $91,9 \%$ yang tergolong 
kategori sangat baik. Dari data hasil belajar tersebut dapat dikatakan bahwa hasil belajar teknik dasar passing-control (kaki bagian dalam) sepak bola pada siklus I ke siklus II mengalami peningkatan sebesar $18,93 \%$ dari $72,97 \%$ menjadi $91,9 \%$.

Berdasarkan uraian di atas, ini berarti bahwa tingkat penguasaan materi teknik dasar passing-control (kaki bagian dalam) sepak bola pada siklus II sudah memenuhi standar ketuntasan secara klasikal yaitu sebesar $75 \%$ sesuai dengan Kriteria Ketuntasan Minimal (KKM) pada kelas kelas X 6 A SMA Karya Wisata Singaraja Tahun Pelajaran 2016/2017.

Berdasarkan uraian di atas, adapun hasil data penelitian siklus I dan siklus II diperoleh rata-rata aktivitas belajar teknik dasar passingcontrol (kaki bagian dalam) sepak bola secara klasikal yaitu sebesar 7,89 yang berada pada kategori aktif. Sedangkan untuk hasil belajar teknik dasar passing-control (kaki bagian dalam) sepak bola secara klasikal yaitu sebesar $82,44 \%$ yang berada pada kategori baik.

Peningkatan aktivitas dan hasil belajar ini dikarenakan penerapan model pembelajaran kooperatif tipe STAD secara optimal dengan perbaikan-perbaikan pembelajaran sesuai dengan kekurangankekurangan yang terjadi pada setiap siklus sebelumnya, disamping itu siswa juga melakukan proses pembelajara dengan sungguhsungguh dan bersemangat pada setiap kelompoknya masing-masing sehingga adanya keterampilan menjalin hubungan antar pribadi siswa seperti kerjasama, tenggang rasa, mandiri serta sopan santun terhadap teman (Nurhadi dkk, 2004:61-62).

Peningkatan aktivitas dan hasil belajar siswa ini tidak terlepas dari kelebihan-kelebihan model pembelajaran kooperatif tipe STAD yaitu setiap siswa menjadi lebih siap dalam mengikuti pembelajaran khususnya dalam pembelajaran teknik dasar passing-control (kaki bagian dalam) sepak bola, serta hasil belajar siswa dapat meningkat karena siswa yang pandai dapat mengajarkan siswa yang kurang pandai yang secara otomatis siswa yang kurang pandai mendapatkan dampak yang positif.

Aktivitas belajar siswa dapat meningkat juga disebabkan karena siswa belajar dan beraktivitas sendiri untuk memperoleh pengalaman, pengetahuan, pemahaman dan tingkah laku lainnya, mampu bekerja sama dengan temannya, mengembangkan keterampilan yang dimiliki serta sudah mulai sangat aktif dan antusias selama proses pembelajaran sehingga dapat memahami materi pelajaran dengan sangat baik khususnya materi teknik dasar passing-control (kaki bagian dalam) sepak bola (Hamalik, 2001:171). Peningkatan aktivitas belajar ini dapat dilihat dari perubahan tingkah laku siswa dari awalnya tergolong kurang aktif pada observasi awal menjadi tergolong aktif pada siklus II sebagai hasil pengalamannya sendiri dalam interaksi dengan lingkungannya, dengan adanya peningkatan terhadap perubahan tingkah laku tersebut maka siswa sudah dikatakan belajar (Slameto, 2003:2).

Berdasarkan hasil penelitian yang telah dilakukan peneliti dan uraian yang telah dipaparkan di atas, maka dapat disimpulkan bahwa Penerapan Model Pembelajaran Kooperatif Tipe Student Teams Achievement Divisions (STAD) dapat meningkatkan aktivitas dan hasil belajar teknik dasar Passing Conrol Sepakbola Pada Siswa Kelas X 6 A SMA Karya Wisata Singaraja Tahun Pelajaran 2016/2017. 


\section{DAFTAR PUSTAKA}

Agus Suprijono. 2009. Cooperative Learning Teori \& Aplikasi Paikem. Surabaya : Pustaka Pelajar

Aip Syarifuddin. 1997. Pendidikan jasmani dan kesehatan 1. Jakarta. PT Gramedia Widiasarana Indonesia

Alenmarlis. 2009. Bedah Penjasorkes Paradigma Baru. file:///H:/BEDAH\%20 PENJASORKES\%20\%C2\%A $\mathrm{B} \% 20$ alenmarlissmpn1 gresikbl ok.htm. (diakses pada 5 maret 2010).

Budi Jatmiko. 2004. "Model-model Pembelajaran (DI, Kooperatif dan PBI)" Makalah dalam Seminar dan Loka Karya bagi Dosen, Guru-guru SD, SMP, dan SMA se-Bali di Fakultas Pendidikan MIPA. IKIP Negeri Singaraja. Singaraja 27 November 2004

Danny Mielke. 2003. Dasar-Dasar Sepakbola. Pakar Raya

Depdiknas. 2007. Peratutran Mentri Pendidikan Nasional Republik Indonesia Nomer 41 Tahun 2007 Tentang Standar Proses Untuk Satuan Pendidikan Dasar Dan Menengah. Jakarta

Dikmenum. 2009. "Mata Pelajaran Pendidikan Jasmani, Olahraga dan Kesehatan untuk Sekolah Menengah Atas (SMA)/Madrasah Aliyah (MA)/Sekolah Menengah Kejuruan (SMK)/Madrasah Aliyah Kejuruan (MAK)".http//dikmenum.go.id/P embelajaran/1.KUMPULAN PERMEN/ 17.STANDAR KOMPETENSI DAN KOMPETENSI DASAR SMAMA/82.Penjas_SMA.doc. (diakses pada 10 Desember 2016)

Dimyati dan Mudjiono. 2006. Belajar dan Pembelajaran. Depdikbud.
Harsuki. 2003. Perkembangan Olahraga Terkini Kajian Para Pakar. Jakarta: PT. Raja Grafindo Persada

Husdarta. 2009. Manajement Pendidikan Jasmani. Bandung : ALFABETA

Kanca, I Nyoman. 2006. Metodelogi Penelitian Keolahragaan.

Singaraja : Jurusan ilmu

Keolahragaan Fakultas

Pendidikan IImu Keolahragaan Universitas Pendidikan Ganesha Siangaraja. 2010. "Penelitian Tindakan Kelas". Makalah disampaikan dalam Pelatihan PTK Guru Penjasorkes SMA/SMK se Bali. Jurusan Pendidikan Jasmani, Kesehatan dan Rekreasi. Fakultas OLahraga dan Kesehatan. Universitas Pendidikan Ganesha Singaraja. Singaraja 6 Agustus 2010.

Lanang Agung Parwata, I G. 2010. Model Pembelajaran Inovatif. Makalah disampaikan dalam Pelatihan PTK kelas Guru Penjasorkes se Bali. Jurusan Pendidikan Jasmani, Kesehatan dan Rekreasi. Fakultas OLahraga dan Kesehatan. Universitas Pendidikan Ganesha Singaraja. Singaraja 6 Agustus 2010.

Luxbacher. 2001. Sepakbola. Cetakan Ketiga. Jakarta: PT. Raja Grafindo Persada.

Muhajir. 2007. Pendidikan Jasmani Olahraga dan Kesehatan. Jakarta. Erlangga

Muslikh. 2009. Mata Pelajaran Pendidikan Jasmani, Olahraga dan Kesehatan. http://www.docstoc.com/docs/ 1992085/12-PENDIDIKANJASMANI -OLAHRAGA-DANKESEHATAN- A . (diakses pada 10 desember 2016). 
Muslimin Ibrahim, dkk. 2000. Pembelajaran Kooperatif Pusat Sains Dan Matematika Sekolah Program Pasca Sarjana. Surabaya : UNESA.

Nana Sudjana. 2004. Penilaian Hasil Proses Belajar Mengajar. Bandung : PT Remaja Rosdakarya Offset.

Nurhadi, dkk. 2004. Pembelajaran Kontekstual dan Penerapannya dalam KBK. Malang : Universitas Negeri Malang.

Nurkanca dan Sunartana. 1992. Evaluasi Hasil Belajar. Surabaya : Usaha Nasional

Oemar Hamalik. 2004. Proses Belajar Mengajar. Jakarta : Bumi Aksara

--------. 2005 Kurikulum dan Pembelajaran. Jakarta : Bumi Aksara 2008 Kurikulum dan Pembelajaran. Jakarta : Bumi Aksara

Pakmuis. 2009. Model Pembelajaran Kooperatif. http://pakmuis.blogspot.com/ 2009/11/model-pembelajarankooperatif.html. (diakses pada 10 desember 2016).

Rahmat. 2009. Pembelajaran Kooperatif.

http://cvrahmat.blogspot.com/ 2009/07/ teoritis.html. (diakses pada 10 desember 2016)

Santyasa. 2005. Belajar dan Pembelajaran. Singaraja : IKIP Singaraja.

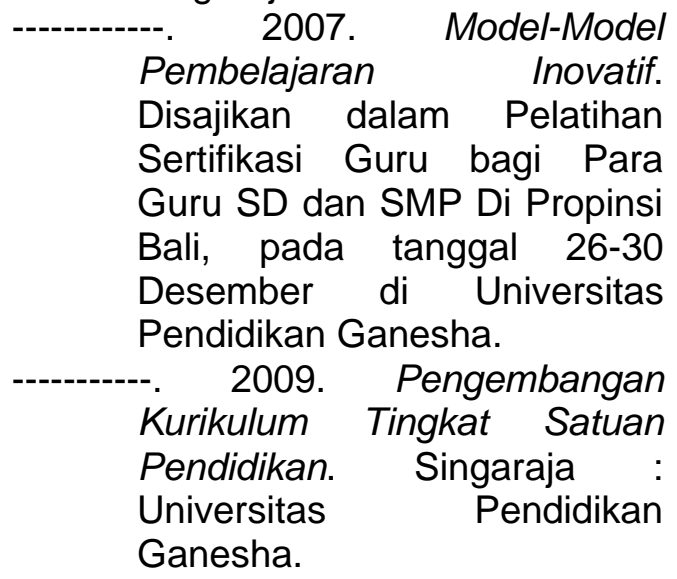

Slameto. 2003. Belajar dan FaktorFaktor yang Mempengaruhinya. Jakarta : Rineka Cipta.

Sugiyanto. 1998. Perkembangan dan Belajar Motorik. Departemen pendidikan dan Kebudayaan Direktorat Jenderal Pendidikan Dasar dan Menengah bagian Proyek peningkatan mutu guru pendidikan jasmani dan kesehatan SD Setara D-II Jakarta. Jakarta : Universitas Terbuka

Sukardjo dan Nurhasan. 1992. Evaluasi pengajaran pendidikan jasmani dan kesehatan. Depdikbud

Sukidin, dkk. 2002. Manajemen Penelitian Tindakan Kelas. Surabaya: Insan Cendekia

Trianto. 2009. Mendesain model pembelajaran inovatif progresif. Jakarta: Prenada Media Group. 